\title{
MILYEN LESZ A JÖVŐ NEMZETKÖZI MARKETINGJE A HATALMI ÁTALAKULÁSOK KÖVETKEZTÉBEN?
}

\author{
KORREFERÁTUM REKETTYE GÁBOR \\ A „A HATALMI ÁTALAKULÁS GLOBÁLIS MEGATRENDJE ÉS \\ A NEMZETKÖZI MARKETING” CÍMÜ TANULMÁNYÁHOZ
}

A gazdasági hatalmi átalakulások globális megatrendje kétségtelenül átrajzolja majd a nemzetközi marketing természetét. Rekettye Gábor vitaindítójára reagálva jelen tanulmány a témával kapcsolatban négy kérdést érint. Az elsố részben a szerzó arra keresi a választ, hogy mennyire lehet hinni a trendekre alapozott prognózisoknak, és milyen kockázatokkal kell számolni? A második rész a gazdasági átrendeződés kulturális következményeit, az urbanizációs folyamatot, valamint a középosztály növekvő fogyasztását veszi górcsố alá. A következtetések arra hívják fel a figyelmet, hogy a jövő nemzetközi marketingje nem hagyatkozhat csak a most uralkodó trendekre: a változásokra vonatkozóan szcenáriókkal kell rendelkezni.

Kulcsszavak: hatalmi átrendeződés, nemzetközi marketing, urbanizáció, multikulturalitás vs. interkulturalitás, növekvő középosztály

A marketing - kialakulása óta - többször került súlyos válságba, és az elmúlt néhány évtizedben számos drámai fordulatnak lehettünk tanúi. Ezeket a válságos időszakokat a marketing mindig túlélte, mindig voltak jó vagy kevésbé jó válaszai a kihívásokra, és azt mondhatjuk, hogy a marketingdiszciplína nem veszített, hanem inkább nyert a megpróbáltatásokból. Az elmúlt évek azonban olyan változásokat hoztak, amelyekre már nehéz lesz gyökeres paradigmaváltás nélkül gyümölcsöző válaszokat adni. A marketing többszörös szorításba került: a globális megatrendek (gazdasági/hatalmi átrendeződés, klímaváltozás, demográfiai trendek, válság, technológiai fejlódés, proliferáció (Rekettye - ifj. Rekettye, 2009, 2013) közül jelen cikk a hatalmi átrendeződés hatásait kívánja vizsgálni a nemzetközi marketingre. A vitaindító tanulmány felvetéseit négy aspektusból egészítem ki: a trendek és prognózisok megbízhatóságára vonatkozóan megfogalmazom kételyeimet, a hatalmi átrendeződés trendjének kulturális következményeivel a nemzetközi marketing jelenlegi értelmezését próbálom megfogni, majd az urbanizációs folyamatok ellentmondásosságát és a „növekvő középosztály növekvő fogyasztását" vizsgálom.

\section{A társadalomtudományi prognózisok és a valóság}

A trend egyfajta fejlődési irányvonalat jelent, a prognózis pedig ezekre alapozva próbál a jövőre vonatkozóan előrejelzéseket adni, kijelentéseket tenni. A vitaindító tanulmány szerzője szerint a XXI. század átalakulásai olyan kihívásokat jelentenek a társadalomkutatók számára, amelyekre az esetlegesen adott válaszok nagyon kockázatosak lehetnek. Magam is azt gondolom, hogy miközben a nemzetközileg elismert szervezetek ezerféle módszert bevetve készítenek prognózisokat, azok gyakran egymásnak ellentmondóak, és talán egyetlen közös jellemzőjük, hogy ritkán jönnek be. Sajnos a társadalomtudományok mindig is ki voltak téve a prognóziskészítés kockázatainak, mert a társadalmat (politikát, gazdaságot, történelmet stb.) emberek alakítják, akik magatartása (nagy szerencsénkre) nem jósolható meg előre. Nem véletlen, hogy a közgazdaságtan matematikai elemzéseit több kritika is érte: gazdaságszociológia (Granovetter - Swedberg, 1992), gazdaságpszichológia (Tversky - Kahneman, 1986), és nem véletlen, hogy az új közgazdasági iskolák: intézményi közgazdaságtan (Coase, 1960), viselkedési közgazdaságtan (Ra- 
bin, 1998), érzelem-gazdaságtan (Hámori, 1998) szinte mindegyike kiemeli az emberi magatartás fontosságát, annak érzékeny pontjait. A gazdaságszociológia álláspontja, hogy a gazdaság társadalmilag beágyazott, a gazdaságpszichológia a homo oeconomicus más értékrendjével operál, az érzelem-gazdaságtan pedig az emberi szenzitivitás jelentőségét hangsúlyozza. A megközelítések közös pontja az, hogy a klasszikus közgazdaságtan racionális fogyasztója nem létezik, vagy ha igen, akkor csak az elméletekben. Amennyiben pedig a változásokat emberek alakítják, kiknek magatartása kiszámíthatatlan (különböző okok miatt nem mindig racionális), akkor a marketingnek e határok között kell megtalálnia az éppen hatékony stratégiákat, eszközöket, azaz nagyon nehéz hosszú távra megjósolni, hogy éppen milyen trendek lesznek a világban, amelyek a marketinget is befolyásolják.

\section{A feltörekvő, szárnyaló országok térnyerése - megállíthatatlan ez a folyamat?}

A vitaindító a hatalmi átrendeződéseket és annak a nemzetközi marketingre gyakorolt hatását tartja az egyik legfontosabb tényezőnek a jövő marketingje szempontjából. Ez a trend szinte megkérdőjelezhetetlen, hiszen a szárnyaló országok térnyerésével kapcsolatban számtalan adatsor rendkívül meggyőző. Nézzük meg a hatalmi átrendeződést alátámasztó prognózisokat! A Goldman Sachs Bankház előrejelzései szerint 2050-re a BRIC-országok megelőzik a világ mai legnagyobb gazdaságait (Wilson, 2003):

„- Az elkövetkező 50 évben Brazília GDP-növekedési aránya eléri a 3,6\%-ot. Brazília gazdasága 2025-re meg fogja előzni az olasz gazdaságot, 2031-re a francia gazdaságot, 2036-ra az Egyesült Államok és Németország gazdaságát.

- Kína GDP-növekedési rátája 2020-ban 5\%-ra esik vissza a tervezett 8,1\%-ról. A 2040-es évek közepén tovább lassul és 3,5\% növekedés várható. Ennek ellenére a magas befektetési arányok, a nagy munkaeró és az állandó konvergencia miatt 2041re Kína a világ legnagyobb gazdasága lesz.

- India GDP-növekedési rátája ez idô alatt (a következő 50 évben) 5\% fölött marad. 2032-re túlszárnyalja Japán gazdaságát és meg van a lehetősége annak, hogy USdollárban számítva 35-szörösére növelje az egy főre eső nemzeti jövedelmét..." (in: Mészáros, 2012, p. 40.).

A közelmúltban új térség jelent meg a feltörekvő országok között, a Dél-Afrikai Köztársaság. "2013-ban a BRICS-országok közel 3 milliárd embert képviselnek, ami mintegy 40\%-a a Föld teljes lakosságának. Az öt ország összesített nominális GDP-je a világ GDP-jének mintegy 20\%-át teszi ki."

Mi lesz a nemzetközi marketinggel, ha ezek az országok tovább növelik erófölényüket a nemzetközi kereskedelemben? Kik diktálják majd a feltételeket? (De biztos, hogy így lesz? A trendek mintha megtörnének: a kínai növekedés lelassult, és ezzel kapcsolatban a szakértók véleménye is megoszlik.)

\section{A hatalmi átrendeződés következményei}

\section{Multikulturalitás vs. interkulturalitás}

A nemzetközi marketing számára a jövőben a kulturális aspektus lehet a leginkább érdekes. A multikulturalitás egyazon társadalomban való megértő együttélést jelent a különböző kultúrák között, míg az interkulturalitás a kultúrák közötti interakciókra fókuszál, ami a kulturális határok átlépésére utal. Megítélésem szerint ezek a kulturális interakciók történhetnek egy adott nemzetállamon belül, de nemzetállamok között is. Mit jelent ilyen körülmények között a külpiac és mit jelent a nemzetközi marketing? A globalizáció kulturális hatásairól három különböző nézet szerepel a szakirodalomban. A kultúrafüggetlen (culture-free) irányzat képviselői szerint a technológiai fejlődés elmossa a kulturális különbségeket, erósíti a konvergenciát, a kultúrafüggó (culture bond) irányzat azonban a mellett voksol, hogy figyelemmel kell lenni a helyi kultúrákra és adaptálni kell az eszközöket, míg a köztes kultúra irányzat képviselői szerint ,a konvergencia és a divergencia egyidejúleg áll fenn. A szituáció dönti el a legmegfelelóbb közelítési módot" (Perlmutter, 1969; Adler, 1983 in: Blahó et al., 2015, p. 26.). Megítélésem szerint a jövőben egy-egy szervezet marketinges elvárások szempontjából nem egy más államba lép be, hanem egy sajátosan globalizálódó, és ugyanakkor nagyon differenciált fogyasztói elvárásokkal rendelkező területen kell múködniük majd a vállalatoknak, függetlenül attól, hogy átléptek-e határokat vagy sem. Egyrészt a mára globálissá (vagy nemzetközivé?) vált szervezetek (McDonalds, Nokia stb.) standardizálni próbálják a sokféle kultúrával, sokféle fogyasztói elvárással bíró csoportok fogyasztói szokásait, másrészt a korábban csak hazai (nemzeti) piacokon múködő vállalatoknak is nemzetközivé kell válniuk, ha meg akarnak felelni a más kultúrával rendelkező olyan vásárlók igényeinek, akik egy adott területen élnek.

A határok lebomlásában, a népesség fokozott mobilitási lehetőségeiben két tendenciát látok: egyrészt a multinacionális és transznacionális vállalatok fogyasztói szokásokat homogenizáló, standardizáló törekvéseit, másrészt a területileg egy helyen megjelenő differenciált kulturális különbségek okozta fogyasztói szokásokat. Ma nem tudnám megmondani, hogy melyik trendnek van nagyobb esélye, de úgy gondolom, 
hogy a nemzetközi marketing meghatározását (és ezzel együtt a vállalatok nemzetközivé válásának fokozatait is) újra kellene gondolni a jövőben. Lesz-e külpiacra lépés vagy nem? Milyen igényeknek kell majd megfelelni: a különbözőségeknek vagy az azonosságoknak, vagy mindkettőnek? Hogyan kell a differenciált elvárásoknak megfelelni, ha a különbségek nem nemzetállamok között, hanem kulturális szokások között lesznek egy-egy területen? Lesznek-e egyáltalán különbségek?

A felvetett kérdésekre nekem az a válaszom, hogy a jövö nemzetközi marketingje többszörös szoritásban van: egyrészt a prognózisok bizonytalanok, másrészt jelen van a globalizáció, harmadrészt megjelennek a helyi differenciált elvárások is. A konvergencia és divergencia együttes jelenléte szerintem hosszú ideig meghatározó lesz a világban.

\section{Merre tart az urbanizáció?}

A jövő trendjeiről az urbanizációs folyamat jelentőségével kapcsolatban is vannak bizonyos kételyeim. Az urbanizáció az ipari forradalommal Nyugat-Európában hirtelen felgyorsult: robbanásszerú volt a falusi népesség városokba áramlása és nőtt a városok száma is. Ez a folyamat a századfordulóig Amerikában is lejátszódott, így talán érthetó, hogy akkor a történészek, geográfusok, szociológusok egy része szerint az volt a jóslat, hogy az urbanizáció folyamata megállíthatatlan, és lassan eltúnik a falusi térség. Az egyik szélsőséges álláspontot többek között $\mathrm{A}$. Toynbee angol történész fogalmazta meg: szerinte a fejlett országok népességének túlnyomó többsége néhány nagy „megapoliszban”, egymással összefüggő, sokmilliós városok övezetében fog élni a XX. század második felére. (Ilyen pl. az Egyesült Államok keleti partvidéke) (Toynbee, 1971). Hasonlóan vélekedett Jean Gottmann francia geográfus is, számára is a megapoliszok voltak a jövő képei (Gottmann, 1961).

Igaz-e, hogy a jövőben is a meghatározó tendencia a lakosság városokba áramlása lesz? Hogyan is kezeljük az urbanizációs folyamatot? Hihetőek-e a vitaindítóban jelzett prognózisok? Enyedi György munkássága éppen erre a megfejthetetlen folyamatra hívja fel a figyelmet. A szerző szerint a településhálózatot olyan dinamikus rendszernek kell felfogni, amely egyensúlyi pályán halad. Ez utóbbi azt jelenti, hogy a népesség térbeli eloszlása optimális a gazdaság fejlődése szempontjából, és az egyensúlyi pálya meghatározásához szükséges a termeló erők területi eloszlási tendenciáinak feltárása. Fentiek értelmében szerinte a modern urbanizáció ciklikus jellegú, amelyben koncentrációs és dekoncentrációs szakaszok váltogatják egymást, és az egyes szakaszok Nyugat-Európából kiindulva fokozatosan az egész földön elterjednek, azaz globális jellegúek (Enyedi, 1984, 1992). Enyedi György közel öt évvel ezelőtt újragondolta elméletét, és megállapításaival nagyon egyet tudok érteni, többek között azért is, mert mintegy megerősít abban, hogy a globalizáció nem mindenható. Ő ugyan a helyi erők jelentőségét emeli ki, de mégis megkérdőjelezi a globalizáció erejét (Enyedi, 2011).

„Vajon a jelen világgazdasági válság nem első jele-e a globalizációs szakasz kezdődő hanyatlásának? A legfejlettebb országokban számtalan jele van a lokális gazdaság erősödésének, a helyi élelmiszerek fogyasztásnövekedésének, a kézmúipari termékek iránti keresletnek, az országon belüli turizmus fellendülésének,.. A hosszú távú gazdasági ciklus változása bizonyos. Ám hogy mikor, milyen módon következik be, milyen urbanizációs hatásai lesznek, arra csak a francia közmondással felelhetek: „Qui vivre, verra”, - aki megéri, meglátja (Enyedi, 2011, p. 18.). Az urbanizációt illetően kétségeim vannak annak fogyasztásra gyakorolt hatásaival kapcsolatban is. A városokba áramló tömegek csak akkor jelentenek majd igazi fogyasztói bázist, ha lesz munkájuk, jövedelmük. Ma a városokba áramló tömegek jelentős része nem talál munkát, és nyomorban él. Ez a gondolat vezet át a középosztály térnyeréséről alkotott véleményemhez.

\section{Vagyoni egyenlótlenségek}

1. ábra
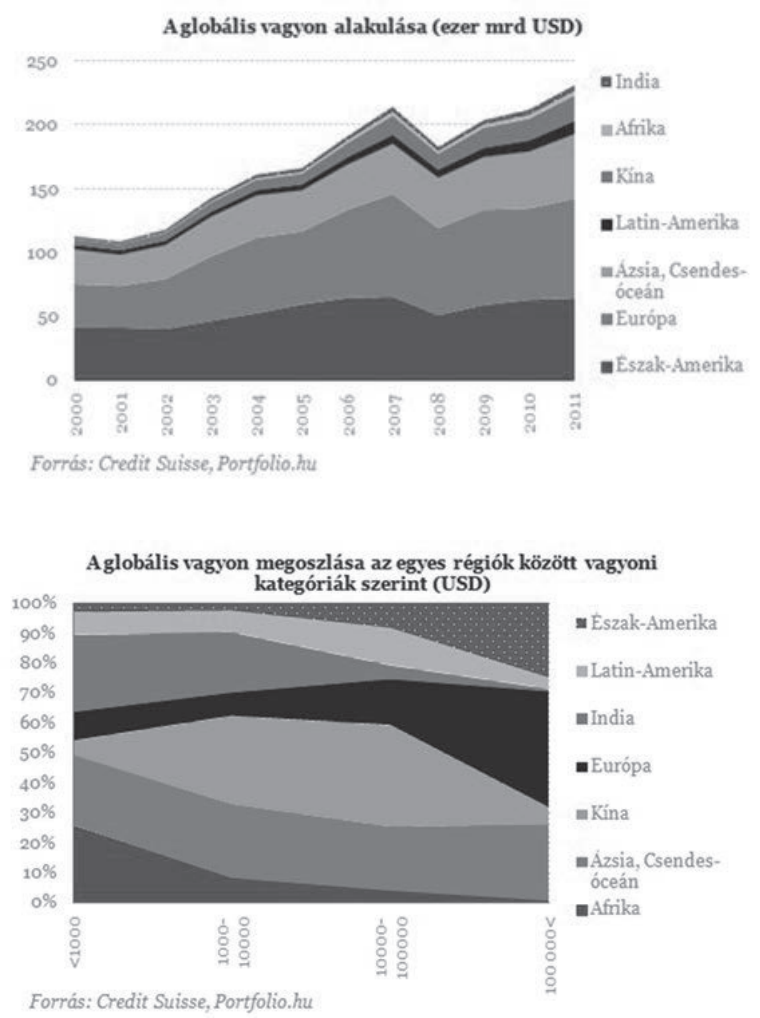

Forrás: Credit Suisse, Portfolio.hu 


\section{A „növekvô” középosztály ,növekvő” fogyasztása}

Lehet, hogy a prognózisok szerint nő majd a középosztály aránya, de mindeközben régiónként változik a középosztály súlya, és hiába nő a középosztály, továbbra is ott lesz a nyitott olló a leggazdagabb és legszegényebb rétegek között. Jelen lesz egy olyan szegény réteg, amely szeretne legalább a középosztályhoz hasonlítani. Velük mit kezd majd a marketing? Ma valóban az a tendencia, hogy a vidéki lakosság a városokban keres boldogulást, így az óriási népsúrűséggel rendelkező megavárosok egyre inkább a szegénység és a szociális összeomlás központjai lehetnek. A világon már ma is csaknem egymilliárd ember - a városi népesség közel fele - él nyomornegyedekben, többségük Afrikában és Ázsiában. Miközben a világ egy része nyomorog, a másik oldalon jelen van a mérhetetlen fogyasztás. Mit tud kínálni majd a marketing a középosztály igényein kívül a luxusfogyasztóknak? A jövedelemegyenlőtlenségek mellett a vagyoni egyenlőtlenségek alakulása még figyelemre méltóbb. (1. ábra)

A vagyoni egyenlőtlenség mértéke az összes vizsgált országban nagyjából kétszer akkora, mint amekkora a jövedelmek közötti egyenlőtlenség. A leggazdagabb tíz százalék rendelkezik a vagyonok 60-70 százalékával, míg a jövedelmeknek csak a 25-35 százalékával (Piketty, 2015). Az azonban itt is igaz, hogy az adatok egymásnak ellentmondóak.

\section{Összegzés, dilemmák}

Elhihetjük-e, hogy a globalizáció abba az irányba tart, amit most jósolnak a nemzetközi szervezetek? Biztos, hogy ezek a trendek érvényesülnek majd? Mi lesz a kulturális átalakulásokkal, mi lesz a gazdag és szegény rétegekkel, merre tart majd az urbanizáció?

Nem tudom mi lesz a jövő, mennyire válnak valóra a prognózisok, de még ha be is jönnek a jóslatok, a jelek alapján az a sejtésem, hogy sokkal differenciáltabb marketingre lesz szükség mind helyi szinten, mind nemzetközileg. Bárhogyan alakul is a trend, a hatalmi átrendeződés más kultúrát jelent majd, és másféle marketinget is igényel. A jövőkutatás nem mindenható, de az előrejelzésekre figyelnie kell a marketingnek, valamennyi globális trendet elemeznie kell, hogy bármilyen változáshoz rugalmasan tudjon alkalmazkodni a jövőben. Bármi legyen is a trendekkel, úgy gondolom, hogy a marketing már több válságon esett át sikeresen (Fojtik - Veres, 2012), így számol azzal, hogy a nemzetközi előrejelzésekre szcenáriókat kell kidolgozni, és „,egy jóslat nem jóslat". Ahogy a prognózisok kiszámíthatatlanok, úgy a fogyasztó is az.

\section{Lábjegyzet}

${ }^{1}$ https://hu.wikipedia.org/wiki/BRICS

\section{Felhasznált irodalom}

Adler, N. J. (1983): Cross-cultural management: Issues to be faced. International Studies of Management and Organization, 1-2: p. 7-45.

Blahó A. - Czakó E. - Poór J. (2015): Nemzetközi menedzsment. Budapest: Akadémiai Kiadó

Coase, R. H. (1960): The Problem of Social Cost. Journal of Law and Economics, 3, October: p. 1-44.

Enyedi Gy. (1984): Az urbanizációs ciklus és a magyar településhálózat átalakulása. Budapest: Akadémiai Kiadó

Enyedi Gy. (1992): Urbanizáció Kelet-Közép-Európában. Magyar Tudomány, 37(99) köt., 6. sz.: p. 685693.

Enyedi Gy. (2011): A városnövekedés szakaszai - újragondolva. Tér és Társadalom, 25. évf., 1. sz.: p. 5-15.

Fojtik J. - Veres Z. (2012): A nagy túléló - Időutazás a marketingben. Budapest: Akadémiai Kiadó

Gottmann, J. (1961): Megalopolis: The urbanized Northeastern Seaboard of the United States. New York: The Twentieth Century Fund

Granovetter, M. - Swedberg, R. (eds.) (1992): The Sociology of Economic Life. Boulder - San Francisco - Oxford: Westview Press

Hámori B. (1998): Érzelem-gazdaságtan. Budapest: Kossuth Kiadó

Mészáros R. (2012): A BRIC-országok. Földrajzi Közlemények, 136, 1: p. 37-45.

Perlmutter, H. V. (1969): The Tortuous Evolution of Multinational Enterprises. Columbia Journal of World Business, 1: p. 9-18.

Piketty T. (2015): A tôke a 21. században. Budapest: Kossuth Kiadó

Rekettye. G. - ifj. Rekettye G. (2009): A világ jövője - a jövő marketingje. Vezetéstudomány, XXXX. Évf. 2. szám: p. 2-9.

Rekettye, G. - Rekettye, G. Jr. (2013): Global Trends and Their Influence on Future Business Performance. International Journal of Business Performance Management (IJBPM), 14, 1: p. 95-110.

Toynbee, A. (1971): Surviving the Future. Oxford: Oxford University Press

Tversky, A. - Kahneman, D. (1986): Rational Choice and the Framing of Decisions. The Journal of Business, 59, 4: p. 251- 278.

Wilson, D. (2003): Dreaming With BRICs: The Path to 2050. - Global Economics, 99, Goldman Sachs Global Economics Website (https://www.gs.com) 16 p. 